subculture members are mostly individually oriented and ordinary people are more socially oriented. The subculture environment' influence on the value-semantic sphere of its representatives was confirmed.

Keywords: the sense of life orientation, values, terminal values, instrumental values, value-semantic sphere, adolescence, adulthood, informal subculture, ontogenetic dynamics.

УДК 159.922.86-056.49

В. В. ЗЛАГОДУХ, А. С. БУНЯК

DOI: https://doi.org/10.35619/prap_rv.vi12.51

\title{
ПСИХОЛОГІЧНІ ОСОБЛИВОСТІ САМОСТАВЛЕННЯ У ПІДЛІТКІВ $З$ ПРОЯВАМИ ВІКТИМНОЇ ПОВЕДІНКИ
}

Стаття висвітлює результати теоретичного та емпіричного дослідження самоставлення у підлітків в умовах навчальної діяльності. Уточнюється сутність понять самоставлення та віктимна поведінка. Виокремлюються психологічні показники само ставлення та складові віктимної поведінки у підлітків. Емпірично встановлені особливості самоставлення в залежності від прояву рівня віктимної поведінки у підлітків.

Ключові слова: самоставлення, віктимна поведінка, учбова діяльність, психологічні особливості, тип рольової віктимності, схильність до віктимної поведінки.

Статья отражает результать теоретического и эмпирического исследования самоотношения у подростков в условиях учебной деятельности.

Уточняется сущность понятий самоотношение и виктимное поведение. Bыделены психологические показатели самоотношения и составляющче виктимного поведенияу подростков. Эмпирически установлены особенности самоотношения в зависимости от уровня виктимного поведения у подростков.

Ключевые слова: самоотночение, виктилное поведение, учебная деяльность, психологические особенности, тип ролевой виктимности, склонность к виктимному поведению.

Постановка проблеми. У нашій країні щорічно здійснюється велика кількість злочинів і головна увага прикута до особи злочинця, а не жертви. Окрім того, рівень задоволеності власним життям в українців досить низький, а вагомими рисами менталітету є жертовність, терплячість, здатність та схильність ставити свої інтереси на останній план. Причини цього явища досить складні, але важливо також розглянути механізми протікання такої форми поведінки.

Рівень результативності досліджень віктимної поведінки досить низький, якщо розглядати психологічний бік цих досліджень в Україні. Проблемі віктимності більше уваги приділяла досі лише криміналістика, а в психологічному погляді на цей аспект на разі є значна прогалина. У той час як зарубіжні вчені використовують поняття "віктимна ментальність" та навіть «віктимна культура», розглядають віктимну поведінку як копінг-стратегію, то у вітчизняній науці немає єдиного погляду на причини виникнення віктимної поведінки, навіть саме трактування поняття невиправдано вузьке, лише в площині криміналістики. Існує потреба в створенні нового психодіагностичного інструментарію, адже методик діагностики віктимної поведінки та їі причин надзвичайно мало. Методи та програми профілактики та корекції теж потребують оновлення та розширення. Саме тому важливо досліджувати тему віктимної поведінки саме з психологічної точки зору. Також, віктимна поведінка набуває особливої актуальності у підлітковому віці. В цей же період у багатьох підлітків присутні психологічні проблеми із самоставленням, а воно є одним з основних регуляторів поведінки та значним чином впливає на поведінкові прояви, в тому числі віктимні. Також, самоставлення пов'язано 3 формуванням моральних норм і уявлень. Зі свого боку, віктимність часто викликана негативними уявленнями про себе. Отже, впливаючи на самоставлення можемо чинити вплив і на прояви віктимної поведінки.

Аналіз останніх досліджень і публікації. Віктимну поведінку в першу чергу розглядає кримінологія та окремий напрямок науки - віктимологія. В вузькому розумінні віктимною поведінкою можна назвати конкретні діяння (дії або бездіяльність), їх сукупність у конкретній ситуації, внаслідок застосування яких людина стає жертвою. В широкому розумінні віктимна поведінка - це складна система взаємодії людини з оточуючим світом, внаслідок якої вона виступає жертвою. 3'ясуванню індивідуально-психологічних властивостей та якостей особистості жертви, що сприяють іï віктимізації, присвячено цілу низку досліджень. Сукупність якостей, явищ, психологічних властивостей, характеристик особистості, що сприяють ії віктимній поведінці та віктимізації, складають віктимність особистості. Віктимність (або віктимогенність) - це набуті Випуск 12, 2019. Збірник наукових праць РДГУ 
людиною фізичні, психічні й соціальні риси та ознаки, котрі можуть зробити ії схильною до перетворення на жертву.

Необхідно зауважити, що віктимність, як особлива властивість особистості й поведінки потенційної жертви, притаманна далеко не всім постраждалим (адже $є$ ситуаційні, випадкові жертви). Це свідчить, що в межах кримінології вирішується ціла низка питань стосовно постраждалих від злочину, які не мають жодного зв'язку з проблемами віктимності. До речі, саме фахівці 3 кримінології, криміналістики, карного процесу прагнуть аналізувати індивідуально-психологічні якості та властивості постраждалих від жертв злочину.

Розробки поняття віктимна поведінка зустрічаються у працях Л. Франкла (аналіз віктимності на психологічному рівні в межах профілактики злочинів), М. Аміра, (особливості поведінки жертв згвалтування), H. Adam, O. Obodaru, A. Galinsky (структурування та класифікація основних форм, типів, моделей віктимної поведінки), О.М. Бондарчука (випадкова віктимна поведінка; стійка віктимна поведінка й злісна віктимна поведінка), А. Бентовім, Е. Бенаму (жорстокість батьків та дефіцит моральності як чинники віктимної поведінки), Н.В. Вострокнутова вплив на «віктимологічну ситуацію» асоціальних взаємини батьків), М.А. Одинцової, Н.П. Радчікова (типи рольової віктимності) та ін. Дослідженням самоставлення займалися Р. Харта, Д. Еейтса, У. Джемса (само ставлення як як складова самосвідомості), І.С. Кона (компоненти свідомості) та ін.

Виклад основного матеріалу дослідження. Головна ознака віктимної поведінки - це здійснення певних дій або бездіяльність, які сприяють тому, що людина опиняється в ролі постраждалої, в ролі жертви. Віктимну поведінку можна розглядати як девіацію, тому що вона наносить реальну шкоду особистості та суспільству в цілому, адже підвищує кількість злочинів. Віктимність в поведінці людини є досить стійкою характеристикою, але при цьому сама людина не завжди вбачає недоцільність такої поведінки. Віктимну поведінку можна вважати соціально не адаптивною, адже частіше за все вона несе за собою досить трагічні наслідки.

У досліджені були використані наступні методики «Тип рольової віктимності» (М.А. Одинцова, Н. П. Радчіков), методика «Самоставлення» (В.В.Столін), методика діагностики керованої проекції (В.В.Столін). Вибірку склали підлітки З3СО №162 м. Києва віком від 14 до 16 років у кількості 57 осіб.

Найбільш повну картину самоставлення особистості можна отримати за методикою «Самоставлення» В.Століна, С. Пантілєєва, що всебічно дозволяє дослідити цей феномен. Результати за методикою представлені у табл. 1 Показник глобального самоставлення визначає загальну тенденцію ставлення до себе. Як видно, більшість вибірки має негативне ставлення до себе. Тобто загальна оцінка власної особистості не надто висока.

Таблиия 1

Розподіл результатів за методикою «Самоставлення»

\begin{tabular}{|c|c|c|c|c|c|c|}
\hline \multirow{2}{*}{ Показник - Рівень прояву } & \multicolumn{2}{|c|}{ Низький рівень } & \multicolumn{2}{|c|}{ Середній рівень } & \multicolumn{2}{|c|}{ Високий рівень } \\
\hline & $\%$ & осіб & $\%$ & осіб & $\%$ & осіб \\
\hline Глобальне самоставлення & 66 & 38 & 24 & 14 & 10 & 6 \\
\hline Самоповага & 60 & 34 & 30 & 17 & 10 & 6 \\
\hline Аутосимпатія & 36 & 21 & 30 & 16 & 36 & 21 \\
\hline $\begin{array}{l}\text { Очікуване } \\
\text { інших }\end{array}$ & 46 & 26 & 30 & 17 & 24 & 14 \\
\hline Самоінтерес & 18 & 10 & 36 & 21 & 46 & 26 \\
\hline Самовпевненість & 46 & 26 & 42 & 24 & 12 & 7 \\
\hline Ставлення інших & 66 & 38 & 24 & 14 & 10 & 6 \\
\hline Самоприйняття & 36 & 21 & 46 & 26 & 18 & 10 \\
\hline Самокерівництво & 47 & 27 & 35 & 20 & 18 & 10 \\
\hline Самозвинувачення & 64 & 36 & 30 & 17 & 6 & 3 \\
\hline Саморозуміння & 42 & 24 & 40 & 23 & 18 & 10 \\
\hline
\end{tabular}

За показником поваги до себе також дуже низькі показники, що виявляє тенденцію до відсутності поваги до себе, а отже може сприяти потраплянню в ситуації насилля. Тобто відсутність поваги до себе скоріш за все буде знижувати рівень чутливості до неповаги з боку інших. Людина, 
що вважає себе не гідною поваги менш вірогідно зможе вчасно зупинити прояв неповаги до себе 3 боку інших або ж зможе зрозуміти, що певні дії відносно неї є вже неповагою та насиллям.

Симпатія до себе на високому рівні лише у третини вибірки, але лише $24 \%$ очікують такого ж позитивного ставлення до себе з боку інших. Така тенденція може свідчити про певний ворожий настрій стосовно інших, негативний досвід взаємодії або проекцію власного ставлення до себе на інших. В той же час, 46\% мають дуже високий інтерес до власної особистості, що характерно для підліткового віку. Саме процес активного самодослідження в процесі якого відбувається постійне порівняння 3 іншими, наявність недостатньої інформації про себе може спричиняти негативне самоставлення. Рівень впевненості у собі загалом характеризується як недостатньо високий. При цьому, ставлення інших до себе оцінюється здебільшого як негативне. Можливо, ці показники заважають підвищитися показнику самоприйняття, який поки що низький у $36 \%$ вибірки.

Самоприйняття відображає наскільки людина на даний момент приймає власні якості як частину себе, оцінюючи їх нейтрально чи позитивно, але не в негативному контексті, приймає їх як частину себе, а не намагається викорінити. Поки що для більшості підлітків це складна задача. Ïх картина знань про себе не повна, а ті уявлення, що $є$, часто не повністю відповідають реальності і програють у порівнянні 3 іншими, що не дозволяє повноцінно прийняти себе. Показник самокерівництва відображає уявлення про власні можливості впливати на власне життя - 47\% вибірки не вбачають такої можливості. Цей показник перкликається 3 рівнем екстернальності. Підлітки недостатньо відчувають відповідальність за власний вибір та життя, що теж негативно може проявлятися в ситуаціях насилля та небезпеки.

Аналогічно, показник самозвинувачення невисокий у 64\%, що також відображає тенденцію до перекладання відповідальності на інших. Також, високе самозвинувачення може породжувати прагнення до самопокарання, що якраз і формує віктимну поведінку. Показник саморозуміння підсумовує попередні результати - воно у підлітків не надто розвинене. Загалом їм важко себе розуміти, вони лише починають повноцінний процес самопізнання, а разом 3 тим їх особистість ще формується і все дуже швидко змінюється у житті підлітка. Тож ці труднощі є закономірними, але від того не легше переживаються підлітком.

На основі попередніх даних, попереднього тестування у ході інших досліджень (в тому числі опитувальника Кеттелла) був сформований короткий психологічний портрет кожного респондента на його протилежність і з допомогою контент-аналізу виявлені показники самоставлення. Результати за методикою керованої проекції Століна представлені нижче (табл. 2).

Таблиия 2

Розподіл результатів за методикою діагностики керованої проекції

\begin{tabular}{|l|c|c|c|c|c|c|}
\hline \multicolumn{1}{|c|}{ Показник } & Симпатія & $\begin{array}{c}\text { Антипа } \\
\text { тія }\end{array}$ & $\begin{array}{c}\text { По } \\
\text { вага }\end{array}$ & Неповага & $\begin{array}{c}\text { Близь } \\
\text { кість }\end{array}$ & Віддаленість \\
\hline Кіл-ть, \% & 24 & 76 & 12 & 88 & 84 & 16 \\
\hline Кіл-ть осіб & 14 & 43 & 7 & 50 & 48 & 9 \\
\hline
\end{tabular}

За результатами методики, можна стверджувати, що більшість респондентів відчула близькість 3 описаним психологічним портретом, що гарантує високу точність подальших результатів. Наявність віддаленості від свого психологічного портрету може свідчити про спрацювання захисних механізмів або ж небажання брати участь у дослідженні. Також, виникає питання до рівень знань особистості про себе. Можливо, уявлення таких підлітків про себе надто сильно відрізняються від реальної ситуації. За показником симпатії-антипатії до характеристик власної особистості, три чверті усіх підлітків виявили скоріше антипатію. Тобто людина 3 таким набором характеристик скоріше не сподобалася б кожному 3 них. Проте, все ж таки чверть 3 респондентів виказали симпатію до власного психологічного портрету, що свідчить про наявність більш позитивного самоставлення. Невисокий відсоток (лише $12 \%$ ) відчули повагу до описаної у портреті людини. Більшість же (88\%) - виказували у своєму відгуку на портрет скоріше неповагу. Тобто вислови, які вони вибирали для відгуку виражали низький рівень поваги до людини, наявність деякої відрази та знецінення описаної особистості.Тож, загалом методика діагностики керованої проекції виявила, що у вибірці наявна тенденція до низького рівня аутосимпатії та самоповаги. Загалом, змішані почуття до власної особистості характерні для підліткового віку, але рівень негативного ставлення до себе явно надто високий, що свідчить про психологічні проблеми в темі ставлення до себе і може бути причиною виникнення проявів віктимної поведінки. 
За результатами діагностики проявів віктимної поведінки респонденти були поділені на дві групи: група № $1-32$ респонденти 3 низьким рівнем віктимної поведінки та група № 2 - 25 респондентів з високим та середнім рівнем віктимної поведінки.

Результати встановленнч відмінностей за показником само ставлення представлені у табл. 3.

Таблиия 3

Порівняльний статистичний аналіз показників глобального самоставлення, самоповаги, аутосимпатії та очікуваного ставлення

\begin{tabular}{|c|c|c|c|}
\hline \multirow[t]{2}{*}{ Показники самоставлення } & \multicolumn{3}{|c|}{ Групи } \\
\hline & $1(n=25)$ & \multicolumn{2}{|c|}{$2(n=32)$} \\
\hline \multirow[t]{2}{*}{ Глобальне самоставлення } & Показник значущості & \multicolumn{2}{|c|}{0,001} \\
\hline & Середнє значення & 20,50 & 35,64 \\
\hline \multirow[t]{2}{*}{ Самоповага } & Показник значущості & \multicolumn{2}{|c|}{0,001} \\
\hline & Середнє значення & 17,56 & 38,02 \\
\hline \multirow[t]{2}{*}{ Аутосимпатія } & Показник значущості & \multicolumn{2}{|c|}{0,001} \\
\hline & Середнє значення & 18,06 & 37,55 \\
\hline \multirow[t]{2}{*}{ Очікуване ставлення } & Показник значущості & \multicolumn{2}{|c|}{0,001} \\
\hline & Середнє значення & 20,64 & 35,53 \\
\hline
\end{tabular}

Математично-статистичний аналіз виявив значимі відмінності у самоставленні підлітків. Відрізняється між групами показник глобального самоставлення. Підлітки з віктимною поведінкою мають значно більш негативне самоставлення. Загалом свою особистість вони оцінюють більш негативно.

Самоповага першої групи теж значимо нижча. Вони не відчувають поваги до власної особистості, а отже схильні дозволяти у відношенні до себе більш негативні вчинки, не очікують поваги від інших. Це може бути однією з причин віктимності - відсутність розуміння проявів неповаги до себе, коли вони ще недостатньо явні.

Респонденти першої групи мають значно нижчу симпатію до себе. Низька аутосимпатія означає негативне ставлення до своєї особистості. Ті уявлення, що підлітки мають про себе, викликають у них негативні емоції, їм не подобаються власні риси характеру та, часто, зовнішності. При цьому, підлітки першої групи не очікують позитивного ставлення до себе і від інших також. Це може бути проявом вивченої безпорадності, або ж проявом відсутності відчуття гідності хорошого ставлення з боку інших.

У табл. 4 представлені результати порівняння двох груп за показниками самовпевненості, самоприйняття та самозвинувачення.

Таблиия 4

Порівняльний статистичний аналіз показників самовпевненості, самоприйняття та самозвинувачення

\begin{tabular}{|c|c|c|c|}
\hline \multirow[t]{2}{*}{ Показники самоставлення } & \multicolumn{3}{|c|}{ Групи } \\
\hline & $1(n=25)$ & \multicolumn{2}{|c|}{$2(n=32)$} \\
\hline \multirow[t]{2}{*}{ Самовпевненість } & Показник значущості & \multicolumn{2}{|c|}{0,001} \\
\hline & Середнє значення & 20,56 & 35,59 \\
\hline \multirow[t]{2}{*}{ Самоприйняття } & Показник значущості & \multicolumn{2}{|c|}{0,001} \\
\hline & Середнє значення & 19,16 & 36,69 \\
\hline \multirow[t]{2}{*}{ Самозвинувачення } & Показник значущості & \multicolumn{2}{|c|}{0,001} \\
\hline & Середнє значення & 39,22 & 21,02 \\
\hline
\end{tabular}

Група підлітків з проявами віктимної поведінки не відчуває достатньої впевненості в собі. Їх рівень впевненості значно нижче, ніж у другої групи. Недостатність впевненості може заважати відстоювати свою кордони, зупиняти негативне ставлення до себе, встановлювати зв'язки з іншими на рівних. Перша група значно менше здатна приймати себе. Характеристики їх особистості для них неприйнятні, вони не здатні прийняти себе з таким набором характеристик, які думають складають їх особистість. Неприйняття себе характерне для підліткового віку, але все ж його рівень у першої 
групи значно вище, ніж у другої. У групи підлітків з проявами віктимної поведінки значимо вищий рівень самозвинувачення. 3 одного боку, це свідчить про високий рівень інтернальності, але з іншого змушує оцінювати себе винним більше, ніж будь-яка інша сторона конфлікту, виправдовувати насильника. Високий рівень самозвинувачення може бути однією з головних причин віктимності, тому що відчуття себе винним може несвідомо змушувати шукати самопокарання, яке можна знайти у ситуаціях небезпеки та насилля.

Результати встановлення відмінностей за допомогою математично-статистичного аналізу представлені у табл. 5

Таблиия 5

\section{Порівняльний статистичний аналіз показників самоставлення у підлітків}

\begin{tabular}{|l|c|c|c|}
\hline \multirow{2}{*}{ Показники самоставлення } & \multicolumn{2}{|c|}{ Групи } & \multirow{2}{*}{ Значимість } \\
\cline { 1 - 3 } & $1(\mathrm{n}=25)$ & $2(\mathrm{n}=32)$ & \\
\hline Прийняття боротьби & $4,12 \pm 1,92$ & $10,56 \pm 4,24$ & 0,001 \\
\hline Уникнення боротьби & $15,88 \pm 1,92$ & $9,43 \pm 4,24$ & 0,001 \\
\hline Антипатія & $2,44 \pm 1,00$ & $0,87 \pm 0,65$ & 0,018 \\
\hline
\end{tabular}

Значима різниця між групами встановлена у тенденції прийняття боротьби-уникнення боротьби. Група з проявами віктимності схильна частіше уникати боротьби. Уникати боротьби означає надати перемогу іншій стороні конфлікту, що означає відмову від своєї сили, а отже прийняття позиції жертви. Постійне уникання боротьби веде до формування вивченої безпорадності та засвоєння ролі жертви за одним з сценаріїв. Закономірно, що у підлітків першої групи також значимо відрізняється рівень антипатії до власної особистості, якщо вже були виявлені відмінності за рівнем симпатії, адже це взаємопов'язані протилежні тенденції. Проте, висока антипатія відображає не лише відсутність симпатії, а й наявність негативного ставлення чи емоційної реакції на власну особистість.

Тож, загалом самоставлення підлітків з проявами віктимної поведінки та без таких проявів досить відрізняється. Група з проявами віктимності має значимо гірші показники самоставлення, особливо в сфері симпатії-антипатії до власної особистості, самоприйняття, самоповаги. Оскільки у групи 3 негативним самоставленням також вищі показники прояву віктимної поведінки, а ці характеристики тісно повязані, ми можемо стверджувати, що психологічна корекція самоставлення має також знизити віктимність у групі.

Висновки та перспективи подальших досліджень. Теоретично проаналізовано підліткове самоставлення та віктимність. Головним фактором формування віктимної поведінки є негативні педагогічні умови в яких розвивається особистість. Тобто фактори виховання мають вирішальне значення. Такі стратегії, як: надмірна байдужість до дитини, фізичне насилля або ж надмірне потурання формують віктимність. Також, відбиток накладають травматичні події, досвід переживання насилля. Встановлено, що діагностичні можливості досить обмежені. Діагностика віктимної поведінки представлена невеликою кількістю приходіагностичних методик. Підлітковий період вважається критичним, переламним, i, власне, періодом виникнення цілісності самосвідомості. Як ми визначили, самоставлення $\epsilon$ актуальним питанням у підлітковий період.

У результаті математичної обробки результатів встановлено, що підлітки 3 віктимною поведінкою мають значно більш негативне самоставлення. Загалом свою особистість вони оцінюють більш негативно. Низька аутосимпатія означає негативне ставлення до своєї особистості. Ті уявлення, що підлітки мають про себе, викликають у них негативні емоції, їм не подобаються власні риси характеру та, часто, зовнішності. При цьому, підлітки з високим рівнем віктимнрї поведінки не очікують позитивного ставлення до себе і від інших також. Підлітки з проявами віктимної поведінки не відчувають достатньої впевненості в собі. Характеристики їх особистості для них неприйнятні, вони не здатні прийняти себе з таким набором характеристик, які думають складають їх особистість. У підлітків з проявами віктимної поведінки значимо вищий рівень самозвинувачення. 3 одного боку, це свідчить про високий рівень інтернальності, але з іншого змушує оцінювати себе винним більше, ніж будь-яка інша сторона конфлікту, виправдовувати насильника. Високий рівень самозвинувачення може бути однією з головних причин віктимності, тому що відчуття себе винним може несвідомо змушувати шукати самопокарання, яке можна знайти у ситуаціях небезпеки та насилля. Підлітки проявами віктимності має вищу залежність та схильні частіше уникати боротьби. Уникати боротьби означає надати перемогу іншій стороні конфлікту, що означає відмову від своєї сили, а отже 
прийняття позиції жертви. Постійне уникання боротьби веде до формування вивченої безпорадності та засвоєння ролі жертви за одним з сценаріїв.

Подальші напрями дослідження ми вачаємо у виявленні психологічних детермінант самоставлення у підлітків з проявами віктимної поведінки.

\section{Список використаних джерел}

1. Анісімов А. І. Віктимна психологія. Системнодіяльнісний підхід до знаходження аверсивного стимула : монографія / А. І. Анісімов, М. С. Матусевич, О. В. Шатровай. - СПб. : РГПУ ім. А. І. Герцена, 2013. - С. 18-28.

2. Волянюк Н. Ю. Віктимологія та агресологія : навч. посіб. / Н. Ю. Волянюк, Г. В. Ложкін, В. В. Папуша. - Рівне : Прінт Хауз, 2010. - 265 с.

3. Квінн Вірджинія Н. Прикладна психологія / Вірджинія Н. Квінн. - СПб. ; М. ; Харьків ; Мінськ : Пітер, 2000. - 560 с.

4. Клачкова О. А. Дослідження віктимного типа особистості / О. А. Клачкова // Амурський науковий вісник. - Комсомольск-на-Амурі : АмГПГУ, 2007. - С. 90-103.

5. Колишко А. М. Психологія самоставлення / А. М. Колишко. - Гродно : ГрГУ, 2004. - 102 c.

6. Малкіна-Пих І. Г. Віктимологія. Психологія поведінки жертви / І. Г. Малкіна-Пих. СПб. : Пітер, 2017. - 832 c.

\section{References}

1. Anisimov A. I. Viktymna psykholohiia. Systemnodiyalnisniy pidkhid aversyvnoho stymula : Monohrafiia / A. I. Anisimov, M. S. Matusevych, O. V. Shatrovaya. - SPb. : RGPU im. A. I. Gertsena, 2013. - S. 18-28.

2. Volianiuk N. U. Viktymolohiia ta ahresolohiia : navch. posib. / N. U. Volianiuk, G. V. Lozhkin, V. V. Papusha. - Rivne : Print House, 2010. - 265 s.

3. Quinn Virginia N. Applying psychology / Virginia N. Quinn. - SPb. ; M. ; Kharkiv ; Minsk : Piter, 2000. $-560 \mathrm{~s}$.

4. Klachkova O. A. Doslidzhennia viktymnogo tipa osobistosti / O. A. Klachkova // Amurskiy naukovyi visnyk. - Komsomolsk-na-Amuri : AmGPGU, 2007. - S. 90-103.

5. Kolyshko A. M. Psykholohiia samostavlenniia / A. M. Kolyshko. - Grodno : GrGU, 2004. - 102 s.

6. Malkina-Pyhh I. G. Viktymolohiia. Psikholohiia povedinky zhertvy / I. G. Malkina-Pykh. SPb. : Piter, 2017. $-832 \mathrm{~s}$.

\section{V. Zlahodukh, A. S. Buniak PSYCHOLOGICAL FEATURES OF SELF-ADJUSTMENT IN ADOLESCENTS WITH VICTIM BEHAVIORS}

The article displays a study of the psychological characteristics of self-relations in adolescents, depending on the level of manifestation of victimization behavior. The relevance of the article is that the victimization behavior acquires a huge influence on the self-attitude in adolescence and becomes one of the main regulators of behavior. Self-relation is connected with the formation of moral norms and ideas about oneself. In this regard, at the theoretical level, indicators of self-attitude and components of victimization behavior in adolescents are highlighted. As a result of the diagnostics and mathematical analysis of empirical data, psychological features of self-relation are revealed depending on different levels of victimization.

As a result of mathematical processing of results, it has been established that teenagers with victimal behavior have a significantly more negative self-esteem. In general, they value their personality more negatively. Low autosimpation means a negative attitude towards one's personality. At the same time, teenagers with a high level of victim behavior do not expect a positive attitude towards themselves and from others as well. Adolescents with manifestations of victim behavior do not feel sufficiently self-confident and have a significantly higher level of self-excuse. Further directions of research we seek to identify the psychological determinants of self-administration in adolescents with manifestations of victim behavior..

Keywords: self-attitude, victimization behavior, learning activities, psychological characteristics, type of role victimization, tendency to victimization behavior. 